\title{
No-tillage systems - reviewing the challenge of adoption in relation to the role of fertiliser placement
}

\author{
P.M.S. LANE ${ }^{1}$ and B.E WILLOUGHBY ${ }^{2}$ \\ ${ }^{1}$ Ballance Agri-Nutrients \\ ${ }^{2}$ Ecometric Consulting Ltd. \\ mlane@ballance.co.nz
}

\begin{abstract}
The adoption of no-tillage systems by New Zealand farmers has been slow, but appears to be gaining momentum driven by economic and soil conservation advantages compared to crop and pasture establishment through cultivation. With improvements in technology and techniques establishment and yields of maize, brassica and pasture from no-tillage is similar to those from cultivation. The role of fertiliser placement in crop establishment by no-tillage and pathways to encourage adoption is discussed.
\end{abstract}

Keywords: No-tillage systems, no-tillage, fertiliser, di-ammonium phosphate, DAP, triple superphosphate, fertiliser placement

\section{Introduction}

Man recognised when he first started growing crops that the practice of cultivation improved production. He shifted his fields to ensure reliable growth with an understanding that only came eons later that the quality of the soil resource played a big part in realising this objective. Today we understand the importance of fertiliser inputs, but do we understand the multitude of other services the soil plays in determining sustainable yields? This paper will explore our understanding of the importance of soil services in sustaining our production systems and specifically the impact of no-tillage compared with traditional cultivation practices have on the soil resource.

No-tillage has been widely adopted in Australia, South America and North America. The drivers for adoption vary considerably and, with the exception of South America, adoption has not been intensive (Baker et al. 2007). We will offer an explanation to be interpreted within a New Zealand farming context, where no-tillage is widely practiced for re-grassing, but as yet not widely accepted for cropping (Baker et al. 2003). We present evidence, both observational and quantitative data, from trials comparing no-till with more conventional tillage practices that show no-tillage systems can be as good as if not better than cultivation from both reliability and economic points of view, and will discuss what appear to be impediments to more widespread adoption.

\section{To till or not to till}

It was thousands of years before man recognised that shifting (slash and burn) agriculture had had its day. Technology in the form of metal implements helped its exit and introduced the advantages of cultivation and stable human settlements. Cultivation causes soil mineralisation, making nutrients available for the germinating seed. Mineralisation can be augmented by adding fertilisers. Technologies exist to identify nutrient requirements and tailor fertiliser products to add the required amount, at the right time to maximise crop performance. Generational experience has led farmers to anticipate an economic return from the investment in a crop grown in a cultivated field. It is well understood that continuous annual cropping using conventional cultivation practices slowly degrades a soil, reducing the biological community, soil organic matter, aggregate size and stability, physical stability and resilience and productive capacity (Dalal \& Mayer 1985). This is a consequence of a combination of factors, including a high harvest index of annual cropping systems limiting the amount of litter return to the soil, soils exposed directly to the elements between crops and the physical damage from repeated cultivation actions.

Intensive soil cultivation upsets the population balances within the soil biota. Predators and disease organisms may be disproportionately reduced compared to pest populations. (East \& Willoughby 1983; Robertson 1987; Kladivko 2001). Intensive cultivation refers to the degree of mechanical disturbance of the soil related to the type of cultivator (e.g. roto tiller/ power harrow/rotary hoe) and the number of passes. Cultivation in the past was used to reduce populations of soil pests, for example grass grub (Costelytra zealandica), to sub-economic damage levels (East \& Willoughby 1983). Later came the understanding that grass grub populations resurged after cultivation which was attributed to the removal of predators from the soil environment and the exposure of potential insect disease organisms to lethal UV light from sunlight (Hutchison et al. 2004).

Intensive and continuous cultivation leads to degradation of soil aggregates, soil structure and loss of soil organic matter (Baker et al. 2007; McLaren 


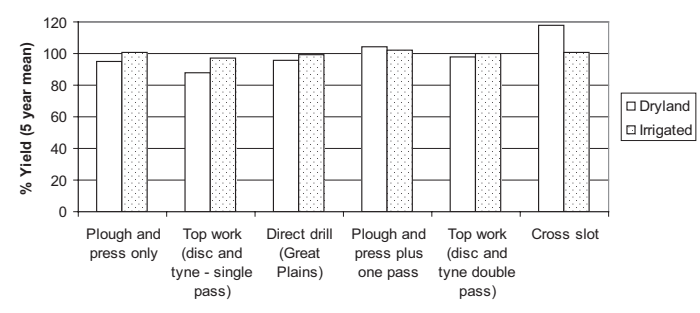

Figure 1 Five year average yield from dryland and irrigated continuous cropping sequence (barley, wheat, peas) established by a variety of cultivation practices (source: Poole 2011).

\& Cameron 1996; Ross 2002; Shepherd et al. 2000; Wanniarachchi et al. 1999). Soil structure, texture and porosity facilitates the movement of air, water and nutrients for plants and provides a cohesive nature and opportunity for roots to penetrate. Loss of cohesion may lead to increased soil loss as sediment which has implications for phosphate loss. Sediment loss into waterways has implications for both eutrification and sedimentation of the waterways and discharge points (estuaries and sea) with detrimental implications for downstream users of these resources (Baker et al. 2007). Loss of soil organic matter has implications for nutrient retention, particularly nitrogen and sulphur and soil aggregate size and stability. Intensive cultivation is also detrimental to the soil biological community. Cultivation, if too deep, may bring unfertile sub-soils into the plant growth zone (Table 1).

No-tillage is a technology driven practice change for farming. The advent of glyphosate in the mid 1970s has offered an opportunity to remove vegetative cover to establish a crop without cultivation. Within 10 years notillage seminars (direct drill, nil cultivation, conservation tillage) were given throughout New Zealand to a farmer audience unprepared for the technological changes. Seed drill technology changed as equipment suitable for placing seed into a prepared seed bed proved inadequate to do so into a recently killed grass sward. The roller drill changed to a triple disc evolving to the sophisticated air drills and openers available today. In the 1980s New Zealand pioneers such as J. Baker and W. Ritchie were able to demonstrate efficiencies from no-tillage (Figure 1). They jointly developed equipment to deliver both seed and fertiliser into a drill row, keeping the two separate (banding) thus alleviating fertiliser "burn"

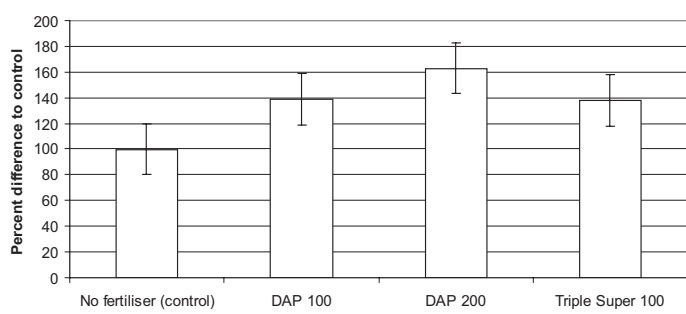

Figure 2 Increase in relative yield of turnips (var: 'Barkant') at 60 days (replicated plots) from inclusion of 100 and $200 \mathrm{~kg} / \mathrm{ha}$ of di-ammonium phosphate or 100 $\mathrm{kg} / \mathrm{ha}$ of triple superphosphate with the seed at sowing by direct drilling. (Ballance field trial data 2008/09)

to the seedling, and were able to demonstrate that notillage could yield crops equivalent to those from a cultivated seed bed.

Adoption of no-tillage systems is usually driven by education, with variable results depending on intensity and continuity of the education programmes (D'Emden et al. 2006). Other pathways have been demonstrated as successful. A novel variation to drive adoption has been the Spokane Rural Loan Program (SRLP) which has loaned \$US5 million dollars to farmers to buy suitable no-tillage drills. Over 80000 ha has been planted using no-tillage methods reducing the losses of soil by erosion rates from $14 \mathrm{t} / \mathrm{h}$ a to $3 \mathrm{t} / \mathrm{ha}$, saving an estimated 1.3 million $\mathrm{kg}$ of $\mathrm{P}$. Projected savings over the 17 years were \$US 18 million (Spokane Conservation District 2011). To protect soils many countries have resorted to regulation with variable results (Blaikie 1985; Napier 1989; Braden 1990; Prazan \& Dumbrovsky 2011). In New Zealand, Regional Councils are recognising the soil management advantages of no-tillage and while at this time are only offering advice (e.g., Rijkse \& Guinto 2010) will probably include requirements for no-tillage more widely in future regional plans. The use of slope as a threshold to reduce sediment and P losses from cultivation is an emerging approach in regional plans (Horizons Regional Council 2012) that might increase the interest in no-tillage systems.

Soil development is a natural process that occurs without cultivation. Implementation of no-tillage systems allow soil building processes to continue by leaving soil structure and predator/pest balance largely unaffected, along with beneficial organisms such as earthworms and natural soil micro-flora - the "natural

Table 1 Changes in fertility of an ash soil (depth 0-150 mm) before and after cultivation (source: Ballance Agri-Nutrients data)

\begin{tabular}{|c|c|c|c|c|c|c|c|}
\hline Fertility & $\mathrm{pH}$ & Olsen P & $\mathbf{K}$ & $\mathbf{S}$ & Mg & $\mathrm{Ca}$ & $\mathrm{Na}$ \\
\hline Pre-Plough September 2004 & 5.9 & 35 & 13 & 60 & 22 & 7 & 5 \\
\hline Post-Plough August 2006 & 6.0 & 9 & 4 & 209 & 32 & 6 & 9 \\
\hline Post-Plough February 2007 & 5.9 & 17 & 13 & 251 & 12 & 6 & 8 \\
\hline
\end{tabular}




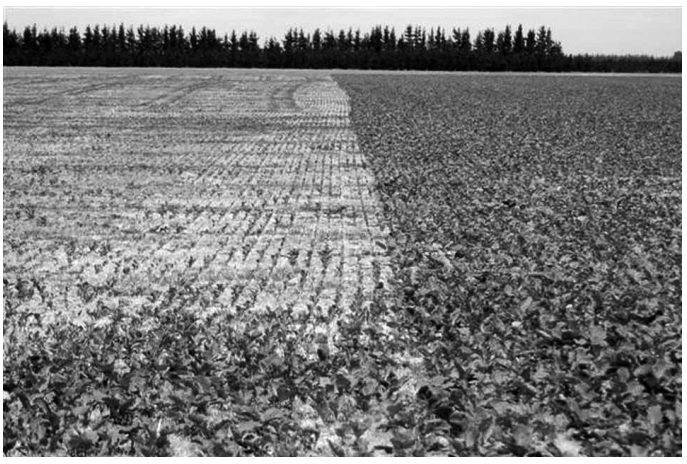

Plate 1

Left side of Photo no till brassica crop 6 weeks post sowing with $350 \mathrm{~kg} / \mathrm{ha}$ of DAP applied to soil surface and right side of photo sample crop with $350 \mathrm{~kg} / \mathrm{ha}$ of DAP banded with seed down the slot . Photo courtesy of Mark Scott No-Tillage, Ashburton, NZ.

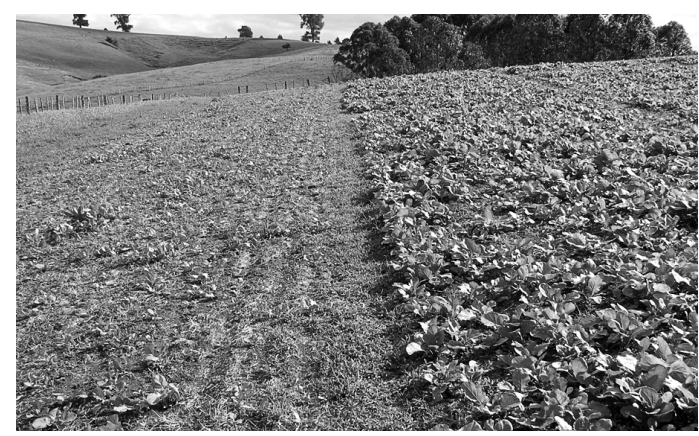

Plate 2

Left side of photo no-till turnips (Brassica rapa var. rapa cult 'Barkant') five weeks post-sowing with no fertiliser addition and on the right side of the photo $100 \mathrm{~kg} / \mathrm{ha}$ of DAP banded with the seed down the slot.

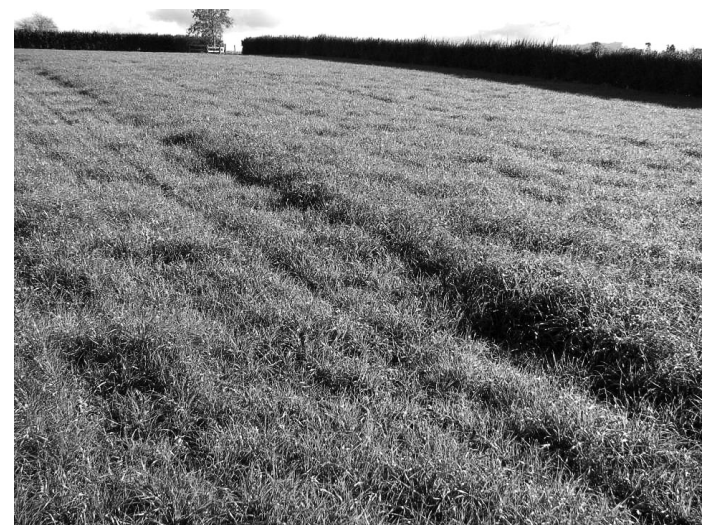

Plate 3

Left side of the photo no-till Italian ryegrass 5 weeks after sowing with no added fertiliser and on the right side $200 \mathrm{~kg} / \mathrm{ha}$ of DAP banded with seed down the slot.

capital" of the soil. With no-tillage systems, the risks from cultivation such as concretions and pans where fine particulate matter binds to impede water movement and root growth, are avoided. Machine time in the field is considerably lessened, as apart from spraying, there is only the need for a single pass with drilling equipment which ensures greater flexibility with respect to sowing and time management. This has economic implications for the farmer, contractor and machinery supplier. In replicated trials 2012/13 the cost of swede and maize establishment using no-tillage was \$200/ha less than the same operation through cultivation without loss of yield. (Lucci et al. 2013; Parker pers. comm 2013)

Maintaining the integrity of the soil structure and preserving a wide range of ecosystem services from the soils, can be captured by reducing cultivation. P loss reduction can occur if sediment loss is reduced (McDowell \& McGregor 1980). Reducing P loss not only benefits the farmer but may serve to enhance economic and recreational opportunities downstream in waterways. Depending on the timing of cover vegetation kill prior to no-tillage crop establishment, there may also be increased soil moisture conservation. "Summer fallow" as a precursor to no-tillage crop establishment was developed in North America and widely adopted for arid Western Australia conditions (Tessier et al. 1990; Radford et al. 1995; Hume \& Lyons 1992; Smith $\&$ Young 2000). Dead plants do not transpire water out of soil and post-spraying plant residues remaining on the soil reduce moisture loss and the hydraulic impact of rain water droplets, increasing water retention and lessening water runoff, soil erosion, and phosphate loss (McDowell \& McGregor 1980).

However, limited soil mineralisation may result in poor seedling establishment, and fertiliser placement in no-tillage may be used to compensate.

Field trials conducted by Ballance Agri-Nutrients in the summer of 2008/09 indicated brassica yield increases from applying fertiliser down the drill with the seed by 40 to $60 \%$. (Figure 3), with the response attributed both to increase $\mathrm{P}$ availability for seedling establishment and to the $\mathrm{N}$ in the DAP. This result appears to be independent of existing soil fertility, and also indicates the practice does not result in measurable seedling loss.

Accepting that the placement of DAP beside the seed may enhance seedling establishment when compared to surface application of the same DAP prompts questions as to amounts and formulation type of $\mathrm{N} \& \mathrm{P}$ for each of the major crops. The graphic visual observations (Plates 1 to 3) serve to highlight the need for investigations to target individual crop/fertiliser response preferably under a range of soil and climate conditions. The fact that most of the $\mathrm{N}$ taken up by the plant is transported by mass flow in the soil, while $\mathrm{P}$ moves by diffusion down a concentration gradient (Caason \& Barber 1976), suggests $\mathrm{P}$ placement may be more important than N. 
While there are indications that DAP at $100-150 \mathrm{~kg} / \mathrm{ha}$ drilled with the seed in $15 \mathrm{~cm}$ rows, is a safe, workable option, we need the research to identify the safety ranges. These studies do highlight the importance of getting the nutrient management right, particularly if adopting no-tillage practices.

In recognising the value of $\mathrm{P}$ at sowing to the developing seedling, and understanding the uptake pathways, the question becomes as to how we can enhance this process. We have shown here that for brassica there appears to be no difference in yield (dry matter at harvest) for crops established with notillage systems verses cultivation (Lucci et al. 2013). Accepting the similarity in outcome in terms of dry matter (DM) at harvest the positive environmental and economic benefits of no-till become a deciding factor. Houlbrooke (2007) in a review of the fertiliser nutrient requirements of direct drilled pastures and crops identified a dearth of New Zealand published literature, necessitating reliance on overseas literature that did not necessarily contain much information on crops favoured in New Zealand such as wheat, barley, brassica and maize.

Shortcomings in the mechanics of no-tillage have for the most part been addressed by improved technology. The role of specific fertilisers in compensating for the lack of natural mineralisation remains only partly clarified. While appropriate use of starter fertilisers with no-tillage may largely overcome seedling establishment variables, other questions remain to be answered. Salt Index and $\mathrm{pH}$ may vary considerably between fertilisers and plant susceptibility/tolerance between species varies as well, posing a risk of seed burn/toxicity to seedlings (Edmeades 2008). Thus questions remain as to what type of fertiliser, how much should be applied, how close fertiliser might be located to a seed. The role of fertiliser coating and the importance of the in slot micro-environment with respect to soil characteristics in no-tillage fertiliser application also require research. Plant nutrient uptake is imperfectly understood. There is no evidence that plant roots can "sense" a nutrient source and grow accordingly. Uptake relies on root interception, mass flow and diffusion, characteristics of specific nutrients. For example most $(80 \%)$ of plant uptake of nitrogen is by mass flow. In comparison, phosphorus $(93 \%)$ and potassium $(80 \%)$, move into the root by diffusion (Mengal 1995). As these figures will vary between individual crops a question might be how the pathway of individual nutrients might be improved in no-tillage systems. In no-tillage, fertiliser may either be sown together with the seed or banded. Banding, placing the fertiliser below or to the side of the seed reduces the risk of seedling burn/toxicity (Baker et al. 2007).
No-tillage is not a panacea. It is not about starting with a "clean slate" as implied with a cultivated seed bed. There is "background noise" to be dealt with. This may be in the form of pests, for example slugs, whose threat must be considered to avoid crop failure. Concentrating nutrients at the soil surface is another issue that must be addressed in no-till systems (Mackay et al. 1987). Weed species are not buried and must be correctly identified and treated with suitable herbicides. The perception that no-tillage crop establishment blankets the landscape with chemicals is a potential barrier to be overcome. Issues such as panning (the development of impermeable soil pans), which may be an artefact of previous over-vigorous cultivation, must be identified and treated as a problematic issue. Notillage needs to be thought of as a system, not just about putting seed into the ground without cultivating

\section{Conclusions}

In terms of soil conservation and economics the case for no-tillage is unequivocally favourable.

Retaining phosphorus within the paddock and away from waterways not only advantages the farmer but will find favour with Regional Councils seeking to implement the Resource Management Act 1992 to lessen the down-stream effects of sedimentation and eutrification.

Cost savings from no-tillage in terms of less money spent on machinery and fertiliser offer a productivity gain and present significant further gains in conservation of the soil biota, and soil structure, the natural capital of the soil.

Research is needed to better define the relative advantages of differing amounts and forms of phosphorus applied with the seed in a range of; soil types, Olsen P and crop. Visual results of field effects of fertiliser placement are indicative. However data is needed from suitably designed field trials.

With change comes the need for education. Targeting both contractors and famers via the printed word on paper and in web sites is limited and inappropriate in today's age of instant gratification. Recipients of information want to know "now" and in a form that suits them, whether it is a card they carry in their ute or access through their phone. No-tillage has floundered in the past from inadequate education and consequent avoidable failures. Some examples include visual "evidence". Most have observed that crops established by no-tillage systems are less "pretty" than cultivated crops. The observer must be trained to look at seedlings emerging through a background of dead plant residue rather than one of a "clean" tilled soil. Seedling emergence may be delayed and variable if not established using best practice no-tillage, but the 
science tells us that the yield from a no-tillage system is the same if not better than from a cultivated seed bed. Education to engender trust in the science is important.

A case for cultivation to establish crops will always exist. Examples include topography or drainage issues that can only be rectified by cultivation. However there is strong evidence related to cost, nitrogen and phosphate loss reduction and protection of soil natural capital that no-tillage systems will become the technology of choice in the future. The challenge is how far away that future is and what can be done to speed adoption.

\section{ACKNOWLEDGEMENTS}

The authors would like to thank Ballance Agri-Nutients for the opportunity to present the case for no-tillage and initiate a discussion as to the role of fertilisers to complement this system approach to pasture and crop establishment.

\section{REFERENCES}

Baker, C.J.; Collins, R.M.; Choudhary, M.A. 2003. Factors affecting the uptake of no-tillage in Australia, Asia and New Zealand. pp. 13-20 In: Conservation Agriculture . Eds. García-Torres, L.; Benites, J.; Martínez-Vilela, A.; Holgado-Cabrera, A. Springer, Netherlands.

Baker, C.J.; Saxton, K.E.; Ritchie, W.T.; Chamen, W.C.T.; Reicosky, D.C.; Ribeiro, M.F.S.; Justice, S.E.; Hobbs, P.R. 2007. No-tillage seeding in conservation agriculture (2nd edition). Food and Agriculture Organization of the United Nations, CABI., United Kingdom.

Blaikie, P. 1985. The political economy of soil erosion in developing countries. Longman, UK ISBN 0-58230089-4

Braden, J. 1990 Policies for soil conservation in New Zealand: options for government. Information Paper No. 31 Lincoln University, Centre for Resource Management.

Caason, N.; Barber, S.A. 1976. Simulation model for nutrient uptake from soil by a growing plant root system. Agronomy Journal 68: 961-964

Dalal, R.C.; Mayer, R.J. 1985. Long term trends in fertility of soils under continuous cultivation and cereal cropping in southern Queensland. Australian Journal of Soil Research 24: 281 - 292

D’Emden, F.H.; Llewellyn, R.S.; Burton, M.P. 2006. Adoption of conservation tillage in Australian cropping regions: an application of duration analysis. Technological Forecasting and Social Change 73: 630-647

East, R.; Willoughby, B. 1983. Grass grub (Costelytra zealandica) population crash in the northern North Island. New Zealand Journal of Agricultural Research 26: 381-390
Edmeades, D.C. 2008. Nutrient Handbook. Ballance Agri-Nutrients. pp. 84

Horizons Regional Council. 2012. Environment Court Decisions Accessed: September 2012. http://www. horizons.govt.nz/about-us/one-plan/appeals-tothe-proposed-one-plan-as-amended-by-decisionsaugust-2010/environment-court-decisions/

Houlbrooke, D.J. 2007. Literature review on the fertiliser nutrient requirements of direct drilled pastures and crops. AgResearch report prepared for Ballance Agri-nutrients.

Hume, D.E.; Lyons, T.B. 1992. Establishment of new pastures free of ryegrass contamination. Proceedings of the New Zealand Grassland Association 54: 151-156

Hutchison, M.L.; Walters, L.D.; Moore, A.; Crookes, K.M.; Avery, S.M. 2004. Effect of length of time before incorporation on survival of pathogenic bacteria present in livestock wastes applied to agricultural soil. Applied Environmental Microbiology 70: 5111-5118

Kladivko, E.J. 2001. Tillage systems and soil ecology. Soil and Tillage Research 61: 61-76

Lucci, G.; Shepherd, M.; Carlson, B.; Lane, M.; Berry, I. 2013. Establishment of winter forage crops on pumice soils - experimental results and farmers perspectives. In: Accurate and efficient use of nutrients on farms. Eds. Currie, L.D.; Christensen, C. L. Occasional Report No. 26. Fertilizer and Lime Research Centre, Massey University, Palmerston North, New Zealand. http://flrc.massey.ac.nz/publications.html.

Mackay, A.D.; Kladivko, E.J.; Barber, S.A.; Griffith, D.R. 1987. Phosphorus and potassium uptake by corn grown under conservation tillage systems. Soil Science Society of America Journal 51: 970-974.

McDowell, L.L.; McGregor, K.C. 1980. Nitrogen and phosphorus losses in runoff from no-till soybeans. Transactions of the ASAE 23: 643-648

McLaren, R.G.; Cameron, K.C. 1996. Soil science: sustainable production and environmental protection. Oxford University Press, Auckland, New Zealand. 304 pp.

Mengal, D. 1995. Roots, growth and nutrient uptake. Purdue University Dept. of Agronomy publication AGRY 95-08

Napier, T.L. 1989. The evolution of US soil conservation policy from voluntary adoption to coercion. pp. 627-644 In: Soil erosion on agricultural land. Proceedings of a workshop sponsored by the British Geomorphological Research Group. Eds. Boardman, J.; Foster, I.D.L.; Dearing, J.A. Coventry, UK.

Poole, N. ; Information Bulletin 2011, Foundation for Arable Research. PO Box 23133 Christchurch 8445 
Prazan, J.; Dumbrovsky, M. 2011. Soil conservation policies: conditions for their effectiveness in the Czech Republic. Land Degradation and Development 22: 124-133

Radford, B.J.; Key, A.J.; Robertson, L.N.; Thomas, G.A. 1995. Conservation tillage increases soil water storage, soil animal populations, grain yield, and response to fertiliser in the semi-arid subtropics. Australian Journal of Experimental Agriculture 35: 223-232

Rijkse, W.C. and Guinto D.F. 2010. Soils of the Bay of Plenty Vol.1, Vol 2, Vol 3. ISSN:1175 9372 Environment Bay of Plenty. Environmental publication 2010/11-1

Robertson, L. 1987. Food habits of pasture wireworm Conoderus exsul (Coleoptera:Elateridae). New Zealand Journal of Zoology 14: 535-542

Ross, C. 2002. The structure and function of untilled soils. In: Proceedings of the Monsanto Conservation Agriculture Seminars.
Shepherd, T.G.; Ross, C.W.; Basher, L.R.; Saggar, S.V. 2000. Soil management guidelines for sustainable cropping. Manaaki Whenua Press, Christchurch. $25 \mathrm{pp}$.

Smith, E.C.; Young, D.L. 2000. Requiem for summer fallow. Choices First quarter 2000 pp. 24-25 http://ageconsearch.umn.edu/bitstream/132112/2/ SummerFallow.pdf

Spokane Conservation District. 2011. Conservation is in our hands. http://www.sccd.org/agriculture.html

Tessier, S.; Peru, M.; Dyck, F.B.; Zentner, F.P.; Campbell, C.A. 1990 Conservation tillage for spring wheat production in semi-arid Saskatchewan. Soil and Tillage Research 18: 73-89

Wanniarachchi, S.D.; Voroney, R.P.; Vyn, T.J.; Beyaert, R.P.; MacKenzie, A.F. 1999. Tillage effects on the dynamics of total and corn-residue-derived soil organic matter in two southern Ontario soils. Canadian Journal of Soil Science 79: 473-480. 